\title{
Lucky Achievement: \\ Virtue Epistemology on the Value of Knowledge
}

Tsung-Hsing Ho

Department of Philosophy, National Chung Cheng University

This is the pre-peer reviewed version, which will published in final form in RATIO

(https://doi.org/10.1111/rati.12188). This article may be used for non-commercial purposes in accordance with Wiley Terms and Conditions for Self-Archiving.

\begin{abstract}
Virtue epistemology argues that knowledge is more valuable than Gettierized belief because knowledge is an achievement, but Gettierized belief is not. The key premise in the achievement argument is that achievement is apt (successful because competent) and Gettierized belief is inapt (successful because lucky). I first argue that the intuition behind the achievement argument is based wrongly on the fact that 'being successful because lucky' implicates 'being not competent enough'. I then offer an argument from moral luck to argue that virtue epistemologists should maintain that knowledge is no more valuable than Gettierized belief.
\end{abstract}

\section{KEYWORDS}

luck; achievement; virtue epistemology; value of knowledge; John Greco; Ernest Sosa

\section{ACKNOWLEDGMENTS}

This research was supported by the Ministry of Science and Technology, Taiwan (106-2410-H194-083). Thanks to Daniel Whiting, Conor McHugh, Anthony Booth, Lee Walters, Chienkuo Mi, Cheng-Hung Tsai, Wen-Fang Wang, Hua Wang, and Karen Yan for their feedback on the earlier versions of this paper. I also grateful to an anonymous reviewer for their helpful suggestions. 


\section{INTRODUCTION}

Virtue epistemologists, like John Greco (2010) and Ernest Sosa (2007, 2011), often advertise their account of knowledge for being able to solve the problems about the value of knowledge. More specifically, they argue that virtue epistemology can explain why knowledge is more valuable than justified true belief that falls short of knowledge (henceforth, Gettierized belief for short) (Jones, 1997; Kvanvig, 2003; Pritchard, 2010). Very roughly, their reasons are that knowledge is an achievement (apt) whereas Gettierized belief is not (inapt) and that achievement is constitutive of our flourishing. Hence, knowledge is more valuable than Gettierized belief.

Virtue epistemology has a unique feature that distinguishes it from other theories of knowledge: that is, it considers knowledge as a kind of cognitive performance and thus epistemic evaluation as a species of performance evaluation. In Sosa's terms, there are three aspects of performance evaluation: success, competence, and aptness (success because of competence). Accordingly, a cognitive performance is successful when the belief that the performance produces is true, competent when the performance is done through exercising one's cognitive abilities or virtues, and apt when the performance is successful because competent. Knowledge is thus apt belief, whereas Gettierized belief is inapt. And apt performance is a better kind of performance than inapt performance.

This account of the value of knowledge has been criticized on several grounds. Jonathan Kvanvig (2003) and Duncan Pritchard (2010) argue that it fails because its account of knowledge is also Gettierized, that is, some Gettierized beliefs are apt. ${ }^{1}$ Daniel Whiting (2012) argues that some achievements are not constitutive of our flourishing because they are easy. I will offer a novel argument to show that, even granted that virtue epistemology can meet the above objections, what virtue epistemologists should maintain is that Gettierized belief (inapt performance) can also be as valuable as knowledge (apt performance). I first argue that virtue epistemologists base their value intuition wrongly on the equation between being inapt and being successful because lucky. Since 'being successful because lucky' often implicates 'being not competent enough', it is not surprising that virtue epistemologists draw the wrong conclusion that inapt performances are inferior to apt ones (sec 3). To see why the equation should be avoided, I examine the concept of aptness in section 2. Finally, in section 4, I show that the achievement argument is also undermined by this equation and offer an argument from moral luck to show that virtue epistemologists should maintain that inapt performances can be as valuable as apt ones.

\section{WHAT IS APTNESS?}

In this section, I examine the concept of aptness. Aptness is defined as 'success because of competence'. The phrase 'success because of competence' indicates that the point of aptness evaluation is to offer a causal explanation of the success. More specifically, aptness evaluation is not just seeking any cause of the success. It is to assess whether the performance's competence can explain why it is successful. When that is the case, the success is attributable to the performance, as Greco explains:

In cases of knowledge, $\mathrm{S}$ believes the truth because S's belief is produced by ability. In Ernest Sosa's terminology, S's belief is 'true because competent'. But what are phrases of the form 'X because Y' getting at in this context? The answer is attribution: In cases of knowledge, S's success is attributable to S's ability, which is to say that it is attributable to S. (Greco, 2012, p.1)

\footnotetext{
${ }^{1}$ However, Carter (2016), Greco (2010, 2011), and Sosa $(2007,2011)$ offer plausible counter-arguments.
} 
But how should 'attributability' be understood? In Greco (2010) and Sosa (2007), attributability is explained in terms of explanatory salience: $\mathrm{X}$ is attributable to $\mathrm{Y}$ (or $\mathrm{Y}$ explains why $\mathrm{X}$ ) if and only if $\mathrm{Y}$ is the most salient cause of $\mathrm{X}$. Why the most salient cause, not the cause or $a$ cause? The reason is that for every event, there are usually multiple causes contributing to it, and not all of them contribute equally. If lightning causes a forest fire, lightning is not the only possible cause. Other causes include the dry and hot weather, oxygen, combustible materials such as woods and grasses. Without any one of these factors, the forest fire might not occur. But usually we think that lightning is the most salient cause, so we attribute the cause of the forest fire to lightning. More accurately, the fact that the forest fire occurs is primarily attributable to lightning, since there are other less salient causes. Thus, when virtue epistemologists say that a performance is apt because its success is attributable to competence, they do not mean that competence is the only cause. Rather, they mean that competence is the most salient cause, among others, of why the performance is successful.

There are, certainly, many factors contributing to the success of a performance. To the present purpose, however, we only need to focus on two factors: competence and luck. For they are what virtue epistemologists mostly focus on. Very often, virtue epistemologists describe inapt performances as ones that are 'successful because lucky' (which I will discuss in the next section). When virtue epistemologists decide whether a performance is apt, they decide whether competence or luck is the most salient cause of its success.

Though the idea of being the most salient cause looks intuitive, things are more complicated than it looks. Greco (2012) distinguishes two versions of this idea: the quantitative account and the qualitative account. The quantitative account maintains that a success is attributable to its competence just in case it depends on its competence more (to a certain degree) than luck. The qualitative account holds that a success is attributable to its competence just in case its competence "contributes to that success in the right way, where "in the right way" means "in a way that would regularly serve relevant purposes" (Greco, 2012, p.14). Greco adopts the qualitative account, but J. Adam Carter (2016) argues, correctly in my opinion, that the quantitative account is preferable to the qualitative account. Furthermore, the qualitative account is not really helpful. Take the following case from Sosa for example:

Apt Shot. Archie took aim and shot skillfully. His shot hit the bull's-eye.

Inapt Shot. Archie took aim and shot skillfully. However, his arrow was blown away by a gust of wind. Fortunately, another gust of wind blew his arrow back to its original trajectory and hit the bull's-eye.

The qualitative account would have to say that Archie's competence contributes to the successfor the purpose of archery - in the right way in Apt Shot but in the wrong way in Inapt Shot. But this is puzzling, since nothing changes on Archie's side. Certainly, in Inapt Shot, Archie's ability - aiming at the target, steadying his body, observing the environmental factors (such as wind) - does contribute in the way that that would regularly serve the purpose of archery. So, the qualitative account has difficulty in offering a clean-cut explanation for Inapt Shot. ${ }^{2}$ On the contrary, the quantitative account offers an intuitive explanation: the success depends more on luck than on competence in Inapt Shot. Henceforth, I will assume the quantitative account, though my arguments should not be affected if one prefers the qualitative account.

In light of the quantitative account, I suspect that one may argue that, in Inapt Shot, the success depends on competence no less than luck so Archie's shot is apt in both scenarios. After

2 Greco may argue that Inapt-Shot is actually apt. However, it contradicts with most people's view. How to decide whether a performance is apt is a tricky task, which I will discuss. 
all, Archie's shot might miss the target were he less competent. This does not affect the quantitative account, however. For the quantitative account implies that borderline cases can easily happen. This is an important feature of virtue epistemology that receives scant attention, and we will see how it affects the account of virtue epistemology about the value of knowledge.

\section{INAPT $=$ SUCCESSFUL BECAUSE LUCKY?}

In this section, I argue that we should resist a simple argument by virtue epistemologists: namely, knowledge (apt performance) is better than Gettierized belief (inapt performance) because a performance that is successful because competent is a better performance than one that is successful because lucky. Understanding why this simple argument should be resisted helps us uncover a fundamental mistake shared by virtue epistemologists.

We can find this simple argument in the following passages from Sosa and Greco:

Suppose that belief to be competently acquired but Gettiered, so that it is true only by epistemic luck [my italics]. ... Inapt performances fall short not only in that they might have been better on relevant dimensions. They fall short in the fuller sense that they fail to meet minimum standards for performances. Because they are inapt, they are therefore flawed: not just improvable but defective. (Sosa, 2011, p.46)

The proposed solution answers even [the value problem of knowledge], respecting the supposition that knowledge is more valuable than all of its parts taken together. This is because success from ability is more valuable than an act that is both successful and from ability, but not successful because from ability. Suppose, for example, that an athlete runs a race in a way that is clearly an exercise of her athletic excellence. Suppose also that she wins, but only because the other runners, some of whom are equally excellent, get sick before the race. Or suppose that she wins, but only because the other runners were bribed. Clearly, neither sort of win is as valuable as it could be. What one really values as an athlete is to win as the result of ability. (Greco, 2010, p.99)

Greco and Sosa both hold that a successful-because-competent performance is better than a successful-because-lucky performance. Why? The passage from Sosa is not helpful since he merely asserts that inapt performances are flawed. So, let me focus on Greco's athlete example. Intuitively, the win because of the athlete's own ability is a better performance than the win because of others' physical difficulties (luck) or even cheating. Since performance evaluation applies to belief and knowledge, virtue epistemology seems to offer a neat solution.

The simple argument, however, is wrong-headed. True, when we say that a performance is successful because lucky, we tend to think that it is inferior to a performance that is successful because competent. But that is because the sentence 'He wins because of luck' often implicates 'be would not win without the luck'. And from 'he would not win without the luck', people tend to infer that he is not competent enough. It is not surprising, therefore, that the simple argument appears to work, since we tend to think that a successful-because-lucky performance is less or not competent and, as a result, inapt performances are worse performances than apt ones.

This tendency is actually manifest in the above quotations from Greco and Sosa. Greco first correctly stipulates 'in-apt as "not "successful because adroit", from which he then wrongly claim that the athlete's inapt performance is 'successful only because lucky'. Similarly, in Sosa's quotation, a Gettierized belief is 'true only by epistemic luck'. Obviously, this is invalid. 'A performance is successful only because lucky' would even more strongly implicate that the 
performance is not competent enough. ${ }^{3}$ But inapt performances could be as successful and competent as apt ones. Clearly, the simple argument is fallacious because the issue is whether apt performances are more valuable than inapt performances that are equally successful and competent. To avoid unnecessary confusion, we need to cancel the implicature by explicitly stipulating the examples of Gettierized performance as being inapt but as successful and competent as their apt counterparts. Let us redescribe Greco's example and test our intuition again:

Suppose, for example, that an athlete runs a race in a way that is clearly an exercise of her athletic excellence. Suppose also that she wins, because the other runners, some of whom are equally excellent, get sick before the race. Or suppose that she wins, because the other runners were bribed. But remember: she, in fact, is truly competent. That is, even if other athletes were in good conditions and competed in the race competently, she might still win the game.

Once the case is redescribed as such, I doubt that we would still have the intuition that this athlete's performance is less good simply because of being inapt in such a way. In both cases, her performances are equally successful and competent. The only difference is that in the inapt case, it is just that other athletes happen to be ill or bribed (not even by her), which has nothing to do with her performance.

Admittedly, people's intuitions differ. Virtue epistemologists may insist that the athlete's performance becomes a worse performance simply because of being inapt, even when it is equally successful and competent. The point of this section is modest: it is to clear up a potential confusion when testing our intuition. We need to bear in mind that inapt performances can be as successful and competent as their apt counterparts. It is true that inapt performances are successful because lucky, but it must be understood in the technical sense explained in section 2 . To say the least, the athlete example is unable to elicit a strong intuition that apt performances are better than inapt ones. And we will see that this confusion affects the achievement argument-probably the most substantial argument virtue epistemologists have for the superior value of knowledge to Gettierized belief.

\section{ACHIEVEMENT AND LUCK}

Greco (2010, ch.6) has a more substantial argument for the superior value of knowledge to Gettierized belief: the achievement argument. The achievement argument can be formulated as follows:

(P1) A performance is an achievement if and only if it is apt;

(P2) Knowledge is apt, and Gettierized belief is inapt;

(C1) So, knowledge is an achievement, and Gettierized belief is not;

(P3) Achievements have a sort of final value, which non-achievements lack;

\footnotetext{
${ }^{3}$ In light of this, it is difficult to see how Greco can describe the athlete's performance as successful only because lucky, but meanwhile maintains that her performance is competent ('an exercise of her athletic excellence'). For if she does run competently, it is wrong to say that she wins only because other runners are sick or bribed. Saying that suggests that she would simply not be competent enough to win the race, if other runners were really competing. Hence, it would be wrong to describe it as a case in which the performance is competent. Competence does not just require the performer to do the best she can. Rather, it requires that the performer can reliably bring success (Greco, 2010, p.77; see also Sosa, 2015, ch.4). If the athlete can win the race only because other runners do not run competently, it is difficult to say that her running is competent. Therefore, Greco's athlete example is inadequate.
} 
(C2) So, knowledge is more valuable than Gettierized belief. ${ }^{4}$

For the sake of argument, I assume that P2 is correct. I argue that either P1 or P3 (or both) is false. For either inapt performances can also be achievements, or they, if construed as nonachievements, are as valuable as apt performances. To begin with, let us look closer to Greco's reason why an apt performance (achievement) is finally valuable:

In the Nicomachean Ethics Aristotle makes a distinction between (a) achieving some end by luck or accident, and (b) achieving the end through the exercise of one's abilities (or virtues). It is only the latter kind of action, Aristotle argues, that is both intrinsically valuable and constitutive of human flourishing. 'Human good,' he writes, 'turns out to be activity of soul exhibiting excellence.' (Greco, 2010, pp.97-98)

We can accept Greco's claim that success through ability is constitutive of human flourishing. The readers should now see where the problem lies in: it seems wrong to say that inapt performances_-when being equally successful and competent—are successful by luck rather than successful through ability. Certainly, in Greco's athlete example and Sosa's archery example, both protagonists exercise their abilities competently. While it is true that luck is prominent in the inapt version of both examples, their abilities are still salient causes of their successes. So, it seems correct to describe their performances as successes through abilities. Imagine a commentator who watch both games comments: 'Their successes are well deserved. Their performances are really competent!' The comment seems fair. Therefore, inapt performances can be achievements and finally valuable.

To make my point more concrete, let us look at another example. To make a befitting example of inapt performance, it is crucial to construe it as being inapt just because luck is more prominent in itself than in the apt case (hence success and competence remain unchanged). This actually follows Linda Zagzebski's famous recipe for Gettierized case (Zagzebski, 1994): a performance, which might be otherwise apt, could become inapt just because of the intervention or presence of luck. Consider the following example of journal publication:

Apt Publication. David submits his paper to Journal of Great Pbilosophy. The journal policy is to reject any paper that does not receive two unanimously positive reports from the reviewers. Both reviewers judge_-correctly, let us assume_-that David's paper is excellent. So David's paper gets accepted.

Inapt Publication. In this scenario, one of the original reviewers is too ill to referee David's paper. The editors replace her with another one. Unfortunately for David, the new reviewer dislikes David's paper just because it argues against his own position regardless of the virtues of David's paper. Lucky for David, the new reviewer becomes seriously injured and unable to referee. The editors know that the original reviewer becomes well and ask her for help. She gives the same positive report. So, David paper gets accepted.

To avoid confusion, let me stipulate that the success condition of David's performancesubmitting a paper to Journal of Great Philosopby for review-is the acceptance of his paper and it is competent in the sense that the paper is truly excellent. In Apt Publication, David's performance is apt because his competence is the most salient cause of the acceptance of his paper. In Inapt Publication, however, David's performance is inapt because it is likely that David's paper would not be accepted-namely, his success is not safe-because of the intervention of luck.

\footnotetext{
4 This argument is modified from Pritchard's formulation (2010, p.67), which is only about whether knowledge is finally valuable.
} 
It seems wrong to say that David's performance in Inapt Publication is not an achievement of David and not constitutive of his flourishing. Clearly, David exercises his philosophical abilities well and writes an excellent paper. True, there is some significant luck in explaining why David's paper gets accepted. But it remains true that David achieves his end through his abilities. To put it another way, it is hard to deny David is equally good as a philosopher in both scenarios, since nothing changes on his side of performance. This means that the publication of his paper in both scenarios contributes equally to his flourishing as a philosopher (which, let us assume, contributes to his flourishing as a human). It would be wrong to say that David's publication in Inapt Publication is less valuable because it means that David in Inapt Publication is not as good a philosopher as he in Apt Publication. So, both performances contribute equally to David's flourishing and are thus equally valuable.

I suspect that some may still beg to differ. If so, I urge them to consider the possibility that luck is significant even in apt cases, to the extent that it is reasonable to conclude that all performances are inapt. Consider the following argument:

(P4) A successful performance is apt if and only if its success depends more on competence than luck;

(P5) For all performances, if they are successful, their success depends more on luck than competence;

(C3) So, all successful performances are inapt.

The crucial premise, of course, is P5. P5 looks ludicrous, but it may not be. For proponents of moral luck, it is well-known that luck significantly affects many dimensions of moral assessment. As proponents of moral luck (Nagel, 1979; Nelkin, 2013) often distinguishes, there are four types of moral luck: resultant, constitutive, circumstantial, and causal. Resultant luck affects whether a performance turns out to be successful. Constitutive luck usually affects competence when there is luck in who we are and what we can. Circumstantial luck can affect all three aspects of performance evaluation: what performances we may have and whether they are successful, competent, and apt depend greatly on what circumstances we happen to be in (I leave causal luck out because it is less relevant to the present purpose). Since luck significantly affects all dimensions of performance evaluation, it seems more ludicrous to say that our successes depend more on us than luck. Hence, all successes are inapt.

Take the athlete for example. Even when it is 'apt', luck still plays a significant role in explaining why she is competent because she may be gifted in running, live in a society where she can receive the best training, and not be ill on the day of race. Luck is also significant in explaining why her performance is ' $a p t$. Let me slightly modify the example. Suppose there is one athlete who is her only contender (so we can ignore the performances of other competitors), who happened to be injured several weeks before the race. Now consider two possibilities:

Apt Atblete. The contender is fully recovered and run competently (let us assume she breaks the record). Nevertheless, the athlete runs faster and wins the race;

Inapt Athlete. The contender has not recovered yet so she quits. The athlete thus wins the race without strong contenders (though she runs equally fast).

In both scenarios, the only changing factor is luck about whether the contender competes. Since it is just a matter of luck whether the athlete's competence is more salient than luck, we can say that her performance is 'apt' or 'inapt' by luck. In other words, if it is reasonable for virtue epistemologists to say that inapt performances are successful by luck, it is also reasonable, in light of the possibility of moral luck, to say that all performances are successful or unsuccessful by luck, competent or incompetent by luck, and apt or inapt by luck. Hence, we can conclude that all performances are inapt because their successes depend more on luck than competence. 
When I say that a performance is 'apt by luck', it may sound an oxymoron because aptness means that a performance's success is not lucky. We see above that aptness is a matter of causal explanation of a performance's success, which can be context-sensitive. In light of the context sensitivity of aptness, we may distinguish between two levels or contexts of causal explanation of a performance's success and aptness. On the first or ordinary level, we often exclude moral luck as a cause of success. The reason may be that moral luck is omnipresent so that we tend to ignore, just like oxygen is usually not featured in an explanation of a fire accident. Or maybe it is offensive in ordinary life to include moral luck as part of the explanation, like saying that David's success and competence as a philosopher are partly due to his ethnicity, gender, or family background. Nevertheless, on the second or reflective level, we may include moral luck to examine the value of one's achievement. So, a performance is first-level apt when its success depends more on competence than first-level luck that excludes moral luck. But it is second-level inapt because moral luck is the most salient cause of its success, competence, and aptness. Accordingly, C3 should be modified as 'all successful performances are second-level inapt'.

Virtue epistemologists cannot save the achievement argument by arguing that an achievement only needs to be first-level apt. For the idea behind the final value of achievement is that it is not something we earn by luck, which does not distinguish between different sorts of luck.

Distinguishing two levels of aptness does not mean that factors on the second level are less real than those on the first level. So it would be wrong to exclude moral luck when reflecting upon whether we earn our success by luck. Since all of the above examples shows that we can achieve the same success by exercising the same competence and it is a matter of luck whether it is apt or inapt, it would be wrong to conclude that only first-level apt performances are achievements because only they are not successful by luck.

Granted that my argument is correct, virtue epistemologists may, instead, maintain that all performances are not achievements and not constitutive of our flourishing, or that successful and competent performances-no matter whether it is apt or inapt-are achievements and constitutive of our flourishing. I prefer the second position, though I will not argue for it here. ${ }^{6}$ My aim of this paper is to show that virtue epistemologists are wrong to claim that knowledge is more valuable than Gettierized belief. Instead, what their account shows is that they are equally valuable.

There might be some concerns. First, one may argue that moral assessment is different from performance evaluation, so moral luck is inapplicable to performance. I disagree. It is clear that

\footnotetext{
${ }^{5}$ Sosa $(2011,2015)$ also famously claims that there can be higher levels of aptness; for instance, knowing full well is apt belief aptly guided by meta-competence (the agent's assessment of their chance of success). However, Sosa's higher levels of aptness remain on the first level of aptness according to my distinction since our concerns are different. Nevertheless, one may think that Sosa's account of knowing full well can explain how certain knowledge is more valuable than Gettierized belief. I have two points in response. First, even if that is true, it still does not show that mere knowledge (apt belief) is more valuable than Gettierized belief. Second, my argument here can apply to full aptness: similarly, whether a belief is fully apt (apt because of meta-competence) is a matter of luck (e.g. see Sosa's description of Diana's shot (2011, p.12)). What explains the extra value of knowing full well is simply the additional level of competence, i.e. meta-competence.

${ }^{6}$ Several empirical studies (Colaço, Buckwalter, Stich, \& Machery, 2014; Turri, 2016, 2017; Turri, Buckwalter, \& Blouw, 2014) show that achievement and knowledge tolerate luck and unreliability, as Turri concludes: 'when the agent repeatedly misidentifies structures as barns, the presence of fakes is an obvious external explanation for her errors, so people do not conclude that she is unable to identify barns. This coheres with recent findings showing that when someone forms a true belief, people's default assumption is that she formed the true belief through a relevant cognitive ability and thus knows' (2017, p.112).
} 
virtue epistemologists intend that their account of performance evaluation applies to all sorts of performances and moral action is certainly a kind of performance. ${ }^{7}$ So, a moral action may be assessed whether it achieves its end (successful), whether it is done reliably and out of the right kind of moral motivations or principles (competent), and whether it achieves its end through moral competence (apt). This also explains why Aristotle's account of final value about achievement is regarded as befitting to virtue epistemologists.

Second, one may think that I confuse moral luck with epistemic luck. While it is widely held that knowledge cannot tolerate epistemic luck, knowledge is compatible with certain types of luck, such as circumstantial luck (Pritchard, 2005, Ch.5.2). For example, Darwin might not discover evolution if he was not born in a rich family or he did not get on board of the Beagle. So, virtue epistemologists may argue that moral luck ought to be excluded from performance evaluation.

However, this actually reveals another problem for virtue epistemology. When it regards epistemic evaluation as a kind of performance evaluation, it is hard to see why moral luck should be excluded since, as we have seen, moral luck affects all aspects of performance evaluation. Furthermore, our concern here is about the value of knowledge rather than the nature of knowledge. The achievement argument trades on the intuition that an achievement should not be successful by luck, which does not distinguish between epistemic and moral luck. So, virtue epistemologists owe us an argument why a successful performance by moral luck can be an achievement whereas one by epistemic luck cannot.

Third, one may respond that the existence of moral luck is controversial. I acknowledge that. For the present dialectical context, however, it is safe to assume the existence of moral luck because virtue epistemologists accept it. Sosa's archery example and Greco's athlete example are both affected by circumstantial luck. Furthermore, proponents of moral luck (Nussbaum, 1986; Williams, 1981) often argue that moral luck is an important element in Aristotle's moral thinking. For example, Aristotle says: 'some think that we are made good by nature, others by habituation, others by teaching. Nature's part evidently does not depend on us, but as a result of some divine causes is present in those who are truly fortunate' $\left(1179^{\mathrm{b}} 20-3\right)$. To be sure, I do not need to prove the truth of P5, but rather to show that virtue epistemologists would have to accept P5.

Finally, one may think that Inapt Performance and Inapt Athlete (perhaps all the inapt cases under discussion) are not really inapt; after all, competence is still a significant cause of their success. However, this should not be regarded as a problem of mine. Since aptness is a matter of whether competence is more salient than luck, borderline cases can occur easily. What Zagzebski's recipe actually teaches us, in the terms of virtue epistemology, is how to produce borderline cases like the ones under discussion. All it needs is to make luck more salient without affecting success and competence. Since my cases, as well as the ones given by Greco and Sosa, are produced in accordance with this recipe, they should be regarded as Gettierized (inapt). Nevertheless, it may enlighten us about the true significance of the Gettier problem, for we may similarly consider some Gettier-style cases not as genuine counter-examples but as borderline cases.

\footnotetext{
${ }^{7}$ For example, Greco says: 'knowledge is a kind of achievement, or a kind of success for which the knower deserves credit. ... This is a ubiquitous and perfectly familiar sort of normativity. Thus we credit people for their athletic achievements, for their artistic achievements, and for their moral achievements' (Greco, 2010, p.7). See also Sosa (2007, p.94) talks about a group of people that collectively save a stranger.
} 


\section{CONCLUSION}

Virtue epistemologists argue that knowledge is more valuable than Gettierized belief because apt performance is constitutive of flourishing but inapt performance is not. They usually support their arguments with examples of performance. However, intuitions about those examples often trade wrongly on the implicature that a luckily successful performance is not competent enough and is not one's achievement, which ignores the fact that it can be equally competent.

Furthermore, the account of epistemic evaluation as performance evaluation invites us to reflect on the effect of moral luck. Since moral luck affects all aspects of performance evaluation, virtue epistemologists are wrong to describe apt performances as 'success through ability' and inapt performances as 'success by luck', which undermines their achievement argument. Given that a performance can be apt or inapt by luck, virtue epistemologists should maintain that knowledge (apt performance) is no more valuable than Gettierized belief (inapt performance). 


\section{References}

Carter, J. Adam. 2016. "Robust Virtue Epistemology As Anti-Luck Epistemology: A New Solution." Pacific Philosophical Quarterly 97 (1):140-155. doi: 10.1111/papq.12040.

Colaço, David, Wesley Buckwalter, Stephen Stich, \& Edouard Machery. 2014. "Epistemic Intuitions in Fake-Barn Thought Experiments." Episteme 11 (02):199-212. doi: 10.1017/epi.2014.7.

Greco, John. 2010. Achieving Knowledge: A Virtue-Theoretic Account of Epistemic Normativity. Cambridge: Cambridge University Press.

Greco, John. 2011. "The Value Problem." In The Routledge Companion to Epistemology, edited by Sven Bernecker and Duncan Pritchard, 219-31. London: Routledge.

Greco, John. 2012. "A (Different) Virtue Epistemology." Philosophy and Phenomenological Research 85 (1):116. doi: 10.1111/j.1933-1592.2011.00567.x.

Jones, Ward E. 1997. "Why Do We Value Knowledge?" American Philosophical Quarterly 34 (4):423-39.

Kvanvig, Jonathan L. 2003. The V alue of Knowledge and the Pursuit of Understanding. Cambridge: Cambridge University Press.

Nagel, Thomas. 1979. Mortal Questions: Cambridge University Press.

Nelkin, Dana K. 2013. Moral Luck. In Stanford Encyclopedia of Philosophy, edited by Edward N. Zalta.

Nussbaum, Martha. 1986. The Fragility of Goodness: Luck and Ethics in Greek Tragedy and Philosophy. Cambridge: Cambridge University Press.

Pritchard, Duncan. 2005. Epistemic Luck. Vol. 29: Clarendon Press.

Pritchard, Duncan. 2010. "Knowledge and Understanding." In The Nature and Value of Knowledge: Three Investigations, edited by Duncan Pritchard, Alan Millar and Adrian Haddock, 3-88. Oxford: Oxford University Press.

Sosa, Ernest. 2007. A Virtue Epistemology. Oxford: Oxford University Press.

Sosa, Ernest. 2011. Knowing Full Well. Princeton, NJ: Princeton University Press.

Sosa, Ernest. 2015. Judgment and Agency. Oxford: Oxford University Press.

Turri, John. 2016. "A New Paradigm for Epistemology From Reliabilism to Abilism." Ergo 3 (8):189-231. doi: 10.3998/ergo.12405314.0003.008.

Turri, John. 2017. "Knowledge Attributions in Iterated Fake Barn Cases." Analysis 77 (1):104-115. doi: 10.1093 /analys/anx036.

Turri, John, Wesley Buckwalter, \& Peter Blouw. 2014. "Knowledge and Luck." Psychonomic Bulletin \& Review 22 (2):378-390. doi: 10.3758/s13423-014-0683-5.

Whiting, Daniel. 2012. "Epistemic Value and Achievement." Ratio 25 (2):216-230. doi.

Williams, Bernard. 1981. Moral Luck. Cambridge: Cambridge University Press.

Zagzebski, Linda. 1994. "The Inescapability of Gettier problems." Philosophical Quarterly 44 (174):65-73. 